\section{Tidlig hjelp til vanskeligstilte barn}

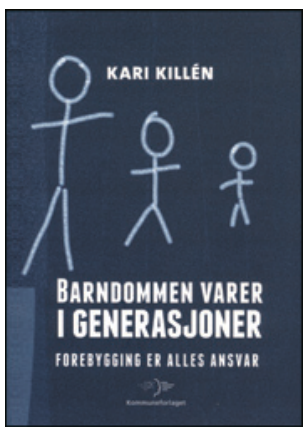

Kari Killén

Barndommen varer i generasjoner

Forebygging er alles ansvar. 3. utg. $246 \mathrm{~s}$. Oslo: Kommuneforlaget, 2013. Pris NOK 370 ISBN 978-82-446-2142-7

Kari Killén har som forsker, kliniker, forfatter og underviser gjennom 40 år bidratt vesentlig til økt forståelse i samfunnet av den risikoen barn som lever under vanskelige oppvekstforhold, utsettes for. Hun har beskrevet symptomer og tegn på omsorgssvikt og overgrep, og påpekt viktigheten av å gi disse barna tidlig hjelp, enten i familien eller ved at de blir tatt ut av familien.

Første utgave av Barndommen varer i generasjoner kom i 2000 og ble anmeldt i Tidsskriftet i mars 2001 (1). Boken henvender seg til alle faggrupper som møter foreldre og barn tidlig i livet, slik som helsesøstre, førskolelærer og lærere, barnevernsarbeidere og fastleger. Den er også nyttig for fagfolk i spesialisthelsetjenesten innen pediatrien og barne- og ungdomspsykiatrien.

Kari Killén oppsummerer i et intervju hovedbudskapet slik: «Det er ikke nødvendigvis slik at et barn som blir slått, kommer til å slå sine egne barn. Men det viser seg at et barn som blir forsømt, ofte gjentar dette på en eller annen måte i forhold til egne barn. Tilknytningsteori, som jeg har jobbet mye med, gir forskningsmessig grunnlag for å si dette. Men vi vet også at dersom barnet får anledning til å bearbeide sine vanskelige opplevelser, eller får en god tilknytning utenfor familien, så kan dette være til stor hjelp. Og derfor er det så avgjørende at vi tenker forebygging så tidlig som mulig. Å reparere skadene på et senere tidspunkt er så mye vanskeligere.» (2)

Kunnskapen om at foreldrenes vansker kan få konsekvenser for barna, kan være vanskelig å ta opp med foreldrene. Det kan være foreldre som selv hadde en vanskelig barndom, og som nå har psykiske vansker, rusproblemer, sosioøkonomiske vanskeligheter, er i konflikt med partneren etc. Boken har mange kliniske eksempler der forfatteren bl.a. viser hvordan man kan ta opp disse temaene på en ivaretakende måte. Hun nevner at det 1.1.2010 kom et tillegg til spesialisthelseloven, hvor man pålegger helseinstitusjoner å ha barneansvarlige som har ansvar for, med foreldrenes samtykke, at barna til pasientene blir informert om foreldrenes tilstand og fulgt opp dersom de trenger det (3). Hun nevner ikke at det på samme tid også kom et tillegg til helsepersonelloven som pålegger alt helsepersonell som behandler pasienter med psykiatrisk sykdom, rusmisbruk eller alvorlig somatisk sykdom, å avklare om de har mindreårige barn og innhente foreldrenes samtykke til at barna blir informert og fulgt opp.

Boken viser hvorfor disse lovendringene er så viktige for å sikre barnas fremtidige psykososiale helse, og jeg anbefaler den på det varmeste.

\section{Marit Hafting \\ BUP Voss}

Voss sjukehus

Litteratur

1. Døssland H. Felles ansvar og utfordringer. Tidsskr Nor Lægeforen 2001; 121 : 854

2. Intervju med Kari Killén. Pedagogisk forum. www.pedagogiskforum.no/ PEDAGOGISK\%20BOKORM/kkintervju.htm (21.5.2013).

3. Tillegg til spesialisthelseloven. www.regjeringen.no/nn/dep/hod/Dokument/ proposisjonar-og-meldingar/Odelstingsproposisjonar/2008-2009/otprp-nr-842008-2009-.html?id=560342 (21.5.2013).

\section{0 år gammal bok i ny omsetjing}

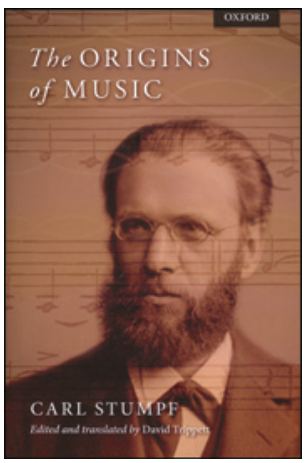

\section{Carl Stumpf \\ The origins of music}

267 s, ill. Oxford: Oxford University Press, 2012.

Pris GBP 35

ISBN 978-0-19-969573-7

Dette er ei ny omsetjing, frå tysk til engelsk, av Carl Stumpf sitt verk The origins of music frå 1911. Boka inneheld òg Carl Stumpf sin autobiografi frå 1923, der Stumpf oppsummerer sitt vitenskaplege arbeid. Målgruppa er alle med interesse for vitenskapshistorie, musikologi, psykoakustikk, musikketnologi, evolusjonsteori, filosofi og kognitiv psykologi. Omsetjar og redaktør David Trippett ønsker å vise korleis Carl Stumpf blei ein pioner innan eksperimentell psykologi. Det blei han gjennom sitt arbeid med å studere persepsjon av lyd og med ein teori for evolusjon av musikk. Han frigjorde dette faget frå filosofi medan han bana vegen for psykofysikk og fysiologi.

Boka har tre delar. Den byrjar med to essay, der lesaren blir introdusert for Carl Stumpf sitt bidrag til ein ny type empiribasert forsking innan psykologi og musikkevolusjon. Forfattarane set arbeidet til Stumpf i ein historisk kontekst, der dei viser korleis Stumpf frå sin ståstad som filosof, via sitt eksperimentelle arbeid med studier av musikkpersepsjon og «The origins of music», leggjer grunnlaget for så vel eksperimentell psykologi og komparativ musikologi, seinare musikketnologi.

Del 2 er ei ny omsetjing av Stumpf sitt orginale verk. Her innleier Stumpf med sitt syn på musikk og evolusjon, og underbyggjer så dette ved ein nøye analyse av musikkopptak frå ulike primitive stammekulturer. Materialet henta han frå dei ca. 30000 vokssylindrane i Berlin Museum of Ethnology/Berlin Phonogram Archive. Han starter med vedakulturen på Sri Lanka og beveger seg vidare austover til Stillehavsområdet, Sør-Amerika, Afrika osb. - jorda rundt. Stumpf var ein svært habil musikar og hadde alle forutsetjingar for analyse av musikken. Sjølv om boka no er 100 år gammal, er den artig å lese. Argumentasjonen er logisk og godt fundert, og teksten virker på mange måter svært moderne. Sjølv om synet på musikkevolusjon kanskje har endra seg noko, står fleire av funna hans fortsatt, til dømes omgrepet «fusion» ved persepsjon av toner, pitch og akkorder, og grunnlaget for konsonans er fortsatt basert på Stumpf sine funn og oppdagingar.

Del 3 er Carl Stumpf sin autobiografi frå 1923, der han sjølv set sitt liv og virke inn i ein større samanheng.

Det som fascinerer mest, er at boka viser korleis ein mann sine nitidige studier av «The psychology of tone» og «The origins of music» danna basisen for to heilt nye forskningsfelt: eksperimentell psykologi og etnomusikologi.

Geir Olve Skeie

Nevrologisk avdeling

Haukeland universitetssjukehus 